\title{
HISTORICAL STRUCTURES AND CULTURES
}

\author{
B. LEFTHERIS \\ Technical University of Crete, Greece.
}

\begin{abstract}
In the early periods of human habitation, nomadic people moved from place to place searching for the means to survive. As civilizations matured, they developed permanent habitations. Others, less advanced warriors, moved in, destroyed the communities and devastated everything in their path. This struggle for survival of the fittest continued for many millennia and especially during the period between the 3rd and 18th centuries in Europe. As an example we refer briefly to the small island of Kythera, in the Ionian Sea. The Spartans, the Athenians, the Byzantines, the Venetians, the French, and the English occupied the island. They built structures that have survived to this day, but the local residents were disingenuous and considered them as aliens. Today there is no connection and no influence between the people on the island and the historical structures the foreigners left behind were abandoned. In Istanbul, on the other hand, no resident can avoid the protective wall structures built by the Byzantines. The Ottomans who conquered Constantinople in 1453 used the architecture of the Christian Hagia Sophia Church to build their own mosques and made more than forty Christian churches their monuments of antiquity: the awareness of the previous cultures is deep and unavoidable. Another example is ancient Rome that conquered ancient Greece militarily while the ancient Greek culture conquered the Romans. The Romans, however, developed their own architecture and especially their own construction engineering. In both cases the conquerors were disciplined by the culture they conquered to reach out beyond themselves. Byzantium was the result of kneading the Greek and Roman cultures with Christianity. This is not the case with New York and Sydney, although they have multicultural societies. Their evolvement is the result of freedom of thought and will that was brought about by social stirrings, the scientific discovery, and the Industrial Revolution of the 19th century. Their evolvement went far beyond their traditional cultures and was determined by utility and technology and certainly by an outburst of individual creativity.
\end{abstract}

Keywords: competitive spirit and social evolution, Istanbul, Kythera, New York City, structures and cultures, structures and human values.

\section{INTRODUCTION}

The idea of comparing cities and cultures was developed during the period of the last five years when the author had the opportunity to visit Istanbul and Sydney, Australia. The author is familiar with New York City, because he lives there for a part of the year. The island of Kythera, on the other hand, was his birthplace.

The initial interest was born over the years as a result of attending the STREMAH conferences (Structural Studies, Repairs, and Maintenance of Heritage Architecture, organized by the Wessex Institute of Technology) since 1991. An additional interest was generated by the excellent book, published recently on Byzantine monuments in Istanbul, written by Freely and Cakmak [1]. Professor Cakmak was born in Turkey; he lived in Istanbul before emigrating to USA to become professor and head of the Civil Engineering Department at Princeton University. He was a STREMAH contributor for years. Their book gave a new emphasis on the Byzantine origins of Istanbul.

New York has an extraordinary architectural variety that is connected with the history of the city and its people and not with kingdoms, empires, or religious orders, although there was a strong European influence in its development. Its recent history is associated with the startling scientific and technological developments during the last one hundred and fifty years. It was the time that the empirical ways of construction gave way to the analytic methods. It was also the time that the people with money and status were searching for new ideas in architecture to immortalize their success.

(C) 2007 WIT Press, www.witpress.com

ISSN: 1744-3687 (paper format), ISSN: 1744-3679 (online), http://journals.witpress.com

DOI: $10.2495 / \mathrm{D} \& N-V 2-N 3-277-282$ 
But most of all it was the place where people from all over Europe had come for a better life, seeking the opportunity to achieve a more prosperous future for their children. It was also the place where individual creativity was rewarded. In many ways their pursuit for a better future was self fulfilling. The dream became reality.

Sydney, Australia, has evolved in a similar fashion; its restrained cultural evolvement, however, had English, European, and American components. Its freedom was moderated by colonial and conservative European attitudes.

Istanbul was rooted in the Byzantine Imperial heritage. Anywhere one goes, the remnants of Byzantium are evident. The Ottoman Empire, like the Byzantine, dictated its architectural development: the Muslim religion became the main carrier, just like Christianity was during the Byzantine era. Ordinary people, however, did not participate in the cultural meaning of any of the historical buildings, nor the development of the city as a whole. Today the main monuments of antiquity in Istanbul are still Byzantine.

In Kythera, a small island in the Ionian Sea, known mostly for its history under Venetian and English governments, the people did not participate in a cultural development. There was no architecture imposed on the island, except for the military forts built by the Venetians and there are no structural monuments indicating their passage, except the bridges and the deteriorated castles they built. Coexistence helped the Kytherians acquire technical knowledge in construction of vaults, bridges, watermills and farming methods. At the time there was a Christian movement that resulted in the construction of three hundred and fifty churches, most of them family churches with some of the best Byzantine icons known today, but they were all through individual efforts and only imposed by the fear of God.

Kythera, along with other Ionian islands, were not occupied by the Ottomans, as was the remainder of Greece for four hundred years. Their cultural habits, however, were very much influenced by the thousands of Kytherians in the cosmopolitan city of Smyrna (modern Izmir), in Asia Minor, where they had emigrated over the years.

\section{ISTANBUL}

The origin of western civilization is the Greek-Roman culture. Constantinople during its one thousand year history was Roman from the fourth to the sixth centuries and during those centuries the religion changed from pagan (ancient Greek) to Christian and the language from Latin to Greek. The resulting culture was called Byzantine after the name of the location where Constantinople (Istanbul) was built [1].

When visiting the old section of Istanbul, one is surrounded by the impressive mosques with their imposing minarets, characteristics of the Islamic religion. The Blue Mosque (Fig. 1) and the Hagia Sophia (Fig. 2) are close to each other, but not only in location: they are similar in architecture. It was Hagia Sophia, the center of Christianity for 916 years, built in the sixth century AD, which established the Justinian architecture with the dome designed by two Greek architects.

The Blue Mosque built in 1603-17 and all the mosques in the city and elsewhere are of the same architecture. Here we see the religious architectural continuity in Istanbul, from the Byzantine era to the Ottoman times. Ahmet Ertug, a well known Turkish architect and photographer in an interview recently stated that 'The Byzantium and the Ottomans cultures are a continuity' [2].

There is even a historic 3,500 year old Egyptian obelisk, brought to the city by the Byzantine Emperor Theodosius, who also built the defensive wall (Fig. 3). There are also many remnants from the days of the Emperor Constantine who wanted to make Constantinople the second capital of the Roman Empire. Walking around the city one sees many neo-classical buildings, built during the 19th and 20th centuries with European taste and know-how. 


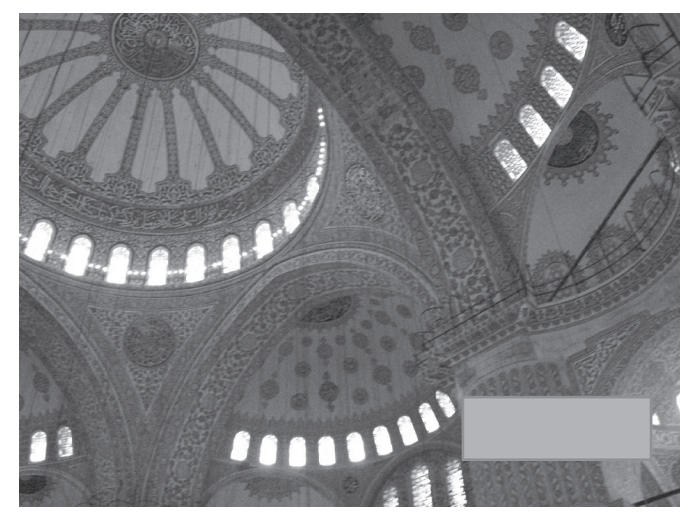

Figure 1: The Blue Mosque, Istanbul.

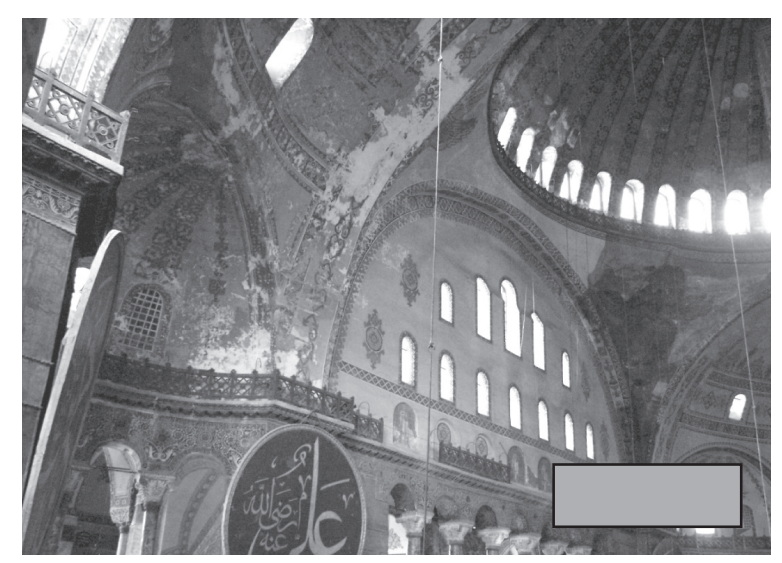

Figure 2: Interior of Hagia Sophia.

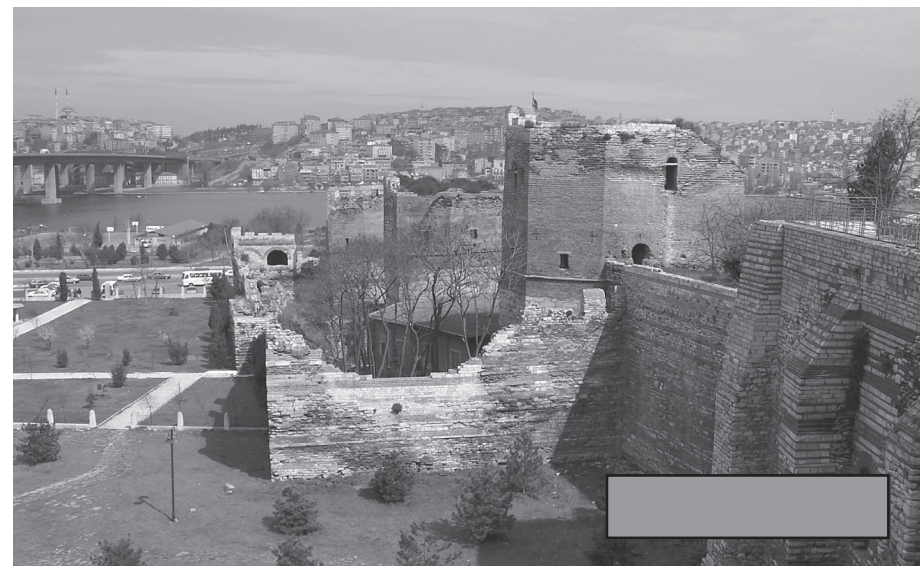

Figure 3: The defensive wall built by Emperor Theodosian. 
One of the most magnificent structures is the Dolmabachce Palace built in 1843-56: it covers an area of 2,500 square meters. The magnificent decorations and its European opulence are impressive beyond description.

These buildings are in sharp contrast with the few multistory buildings, primarily hotels. The rest of the city is spread out in residential dwellings of similar architectural style. In the old Greek neighborhoods of the city we find thirty-eight Christian Churches, maintained as monuments by the City Department of Culture.

In comparison with New York City, there is no architectural individualism. The wars that determined the fate of Istanbul over the centuries were between empires, not between people struggling for a better social status.

There are other similar examples, such as Venice, Florence, and Bologna in Europe. None of them, however, has such a long architectural history as Constantinople does, their main development was the result of the Renaissance period: they were built by centralized powers, like the Medici family in Florence.

\section{NEW YORK}

The history of New York City, in comparison with Istanbul, is recent [3]. After the war against Spain and the defeat of the Spanish armada in 1588, the Dutch and later the English settled in the city. Motivated by trade opportunities, the Dutch established settlements at the tip of Manhattan, because the Hudson River was extending north, connecting with canal systems that reached as far west as Ohio. Due to the European conflicts at that time many Europeans emigrated to America. Until 1920 there were no restrictions of entry, except for the medical examinations at Ellis Island. Whole families of Jews, Italians, Greeks, Germans, Irish, Polish, Maltese, and Russians moved to the New World. As the population increased, New York expanded from the southern tip of Manhattan northward. All these different nationalities came from uniform ethnic backgrounds, but when they came to New York they had to learn to live amicably together. Although the competition for jobs, politics, and religion caused many conflicts over the years, it was out of these conflicts that a multicultural society was hammered out. Because of its geographic location, $80 \%$ of American industry during the 19 th century was located in New York City. The commercial competition was fierce; the most successful became rich and started to build large and tall buildings.

Slowly a new social phenomenon appeared that was different from the Old World. What was socially and politically acceptable was no longer judged by anyone particular ethnic tradition, but by a new consensus of all nationalities. The consensus did not happened overnight, but over a number of years in a social tug of war. It was then possible for new ideas, in all aspects of life, to be considered and exploited. And so it was with new buildings, new products, songs, the theater, then new bridges and the subway. Because of the concentration of wealth, the banking system flourished and technological advances found their way to products for every day's use. Venture capital was easily available and instead of skepticism, there was daring. The result is what one sees today. The city became an incubation place for successful people. Those who could not hack it were lost in the stampede. Over the years as the successful moved to better neighborhoods, different nationalities moved into the vacated places in New York. Following the European influx, came Mexicans, Chinese, South Americans, Arabs, and Vietnamese.

The architecture in New York City reflects its history (Fig. 4). Initially there were buildings of religious meaning, cathedrals for the faithful. But then utilitarian buildings emerged that surpassed the cathedrals in height and volume. Most of all New York became the showcase for the best-known architects. Walking the streets of New York you feel that all these buildings have a personality of 

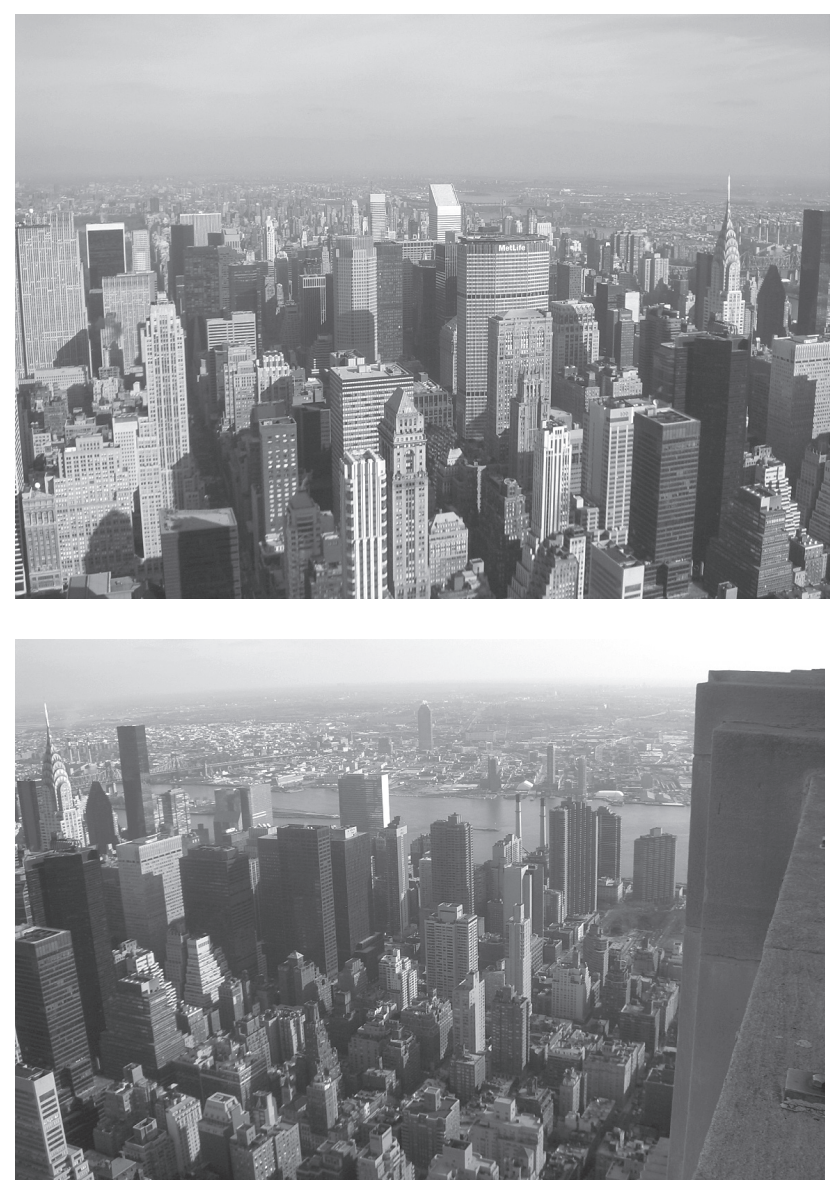

Figure 4: New York City.

their own that motivate the humans of New York City to accept each other and live in a peaceful coexistence.

New York became more of a cosmopolitan place after the Second World War when the United Nations building was constructed there. One important social characteristic of the city over the years is the generosity of its people toward theaters, museums, and libraries. It is perhaps the inspiration that transforms people when they live and prosper in the city that motivates their generous spirits.

\section{THE RELATIONSHIP OF ORDINARY PEOPLE WITH STRUCTURES}

Most of the heritage structures that we studied are historically renowned buildings. They were constructed by Emperors, Religious Institutions, Kings, and very rich people, like, Woolworth, Rockefeller, and Chrysler. The high architecture was a display of their high achievements, and often had the purpose to generate fear and awe in those who look upon them. However, there are many ordinary family dwellings in New York, Istanbul, and elsewhere passed on from generation to 
generation for many centuries: they are also heritage structures, not so much due to their architectural uniqueness, but because of their social and cultural meaning perpetuated through time [4].

As a simple example, many people born on the Greek island of Kythera emigrated to New York toward the late 1800s and early 1900s. When, during the decade of 1930, the land owners of the Venetian period sold their 200-400 hundred year old family homes and property in Kythera, it was the Kytherians who returned to the island from New York with money who bought them. It was not for commercial exploitation, but to restore their social status and to marry women from a better stock of that society. They left penniless and they retuned with both knowledge and money. It was also the opportunity for the old houses to survive.

When immigrants left the island later, during the 1940s and 1950s they literally abandoned what they thought as insignificant family homes: today those homes are wrecks, without roofs, and windows. In their structural nakedness they look sad, morning the loss of their human value.

In Istanbul and other interior cities of Turkey, where there was a population exchange between the Greeks of Turkey and the Turks of Greece in the 1920s, many houses were also left abandoned to decay over the years without anyone to care for them.

In today's economic mentality, people do not hesitate to sell their ancestral homes for something better, in a better neighborhood, without regard to their heritage value. Many estates were sold in England in the early part of the 20th Century, because their owners could not bear the tax burden. Those who bought them maintain their heritage value and share their pride.

\section{CONCLUSIONS}

We can conclude that heritage structures possess religious, cultural, economic, historical, architectural, and family values. Most of these structures maintain their elegance from one generation to another and from one culture to another, whereas others loose their values and deteriorate to oblivion. To the citizens that live and work around them every day, they represent historical values of human continuity. These values cannot be taught in a class with words of logical explanations only: because the process of becoming aware of the past and conscious of the deeper meaning of heritage structures is emotional as they play an important part in our self awareness and cultural maturity.

We must also consider the bond between humans and ordinary family dwellings, farmhouses, watermills, and other modest structures that nevertheless contribute to our cultural evolution.

What is so extraordinary of today's period of human evolution is the recognition of these heritage values as a universal culture and mainly through the advances of the communications media: they transcend ethnic boundaries.

\section{REFERENCES}

[1] Freely, J. \& Cakmak, A., Byzantine Monuments of Istanbul, Cambridge University Press: UK, 2004.

[2] Ertug, A., Byzantium and Ottomans are a Continuity, interview published in the newspaper Kathemerini, Athens, Greece, 25 February 2007.

[3] Homberger, E., The Historical Atlas of New York City, Henry Holt and Company: New York, 1994.

[4] Ballantyne, A., Architecture: A Very Short Introduction, Oxford University Press: Oxford, 2002. 